\title{
Do government appropriations and tax policies impact donations to public research universities in Japan and the USA?
}

\author{
Fumitake Fukui ${ }^{1}$
}

Published online: 7May 2020

(C) The Author(s) 2020

\begin{abstract}
As constraints on government funding to public universities become a trend in higher education internationally, clarifying the impact of government policies on donor behavior from a comparative perspective is an issue of higher education research. This paper aims to explore the impact of government appropriations and tax policies on macro trends in donations to public research universities in Japan and USA. Panel data of donation revenue to public research universities in both countries is used to answer the following two research questions: (1) whether the trends in capital markets affect the donation revenue of public research universities operating under different tax systems in Japan and USA, and (2) how the level of government support to higher education affects donations to American and Japanese public research universities. The primary finding is that stock prices are positively associated with donations in USA; however, there is no evidence that stock prices have a positive impact on donations to Japanese public research universities. These contrasting results imply that higher stock prices do not always induce donations to universities and that it is important to consider each country's tax structure when looking for possible links between stock prices and donations to universities. Also, donor behavior is independent of the amount of government appropriations received by universities in both Japan and USA; therefore, the recent decreasing trends in government appropriations in both countries do not necessarily attract donors.
\end{abstract}

Keywords Donations · Tax policy · Capital market · Government appropriations · Public research universities

Fumitake Fukui

f.fukui@kamakura-u.ac.jp

1 Research Institute, Kamakura Women's University, 6-1-3 Ofuna, Kamakura, Kanagawa 247-0056, Japan 


\section{Introduction}

Higher education's financial viability has become a common policy issue in OECD countries (OECD 2007). Due to higher education's massification and the move toward a knowledgebased society, research universities are expected to provide students with high-quality education and to contribute to society through their research, particularly to national economic prosperity (Slaughter and Leslie 1997). The creation of world-class universities with ample financial resources has become an important government policy issue worldwide (Salmi 2009).

Although Japan has 86 national, 90 public municipal, and 604 private universities, the national universities are especially important in providing high-quality teaching and research. For example, the top ten Japanese universities in the Times Higher Education Ranking in 2018 were all national universities. ${ }^{1}$ While Japanese national universities have mainly relied on government financial support unlike private universities, government funding constraints make it difficult to continue relying on government support. In 2004, when Japan's national universities were converted from governmental organizations to independent administrative entities called "national university corporations," the Japanese government reduced the annual operating grants of Japanese national universities by 1\% (Kaneko 2009). Since then, there has been a clear trend toward decreased government appropriations to national universities.

To maintain or improve higher education and research activities' quality, Japanese policymakers and university administrators sought donations to support higher education. Before 2004, Japanese national universities were considered governmental organizations and had rarely engaged in fundraising; however, since then, they had to adapt to endowments and fundraising. Simultaneously, Japanese donations have not increased dramatically. Accordingly, increasing private donations has become a key government policy. The Japanese Central Council for Education (2018) stated that, "In order to secure stable financial resources for higher education institutions, it is essential for the government to foster a donation culture, and for universities not to rely only on government support but to attract donations from companies, local governments, and individuals through proactive effort" (p. 47). In this context, this paper focuses on the relationship between government public policy and donations to public research universities in Japan ${ }^{2}$ as compared with the USA.

Comparing the determinants of donation trends in Japanese and the US public research universities from the mid-2000s through to 2010s is the rationale for exploring key factors that affect donation revenue macro trends. Japan and USA can be regarded as fitting the "most similar system-different outcomes" (Przeworski and Teune 1970) model, a basic comparative research approach for empirical testing of theoretical proportions. This approach corresponds with the "method of difference" in Mill's (1843) classic study and identifies cases that maximize the variance of the dependent variable and minimize the variance of the independent variables except for the independent variable of interest (Gerring and Cojocaru 2016).

\footnotetext{
${ }^{1}$ The World University Rankings 2018 was retrieved from https://www.timeshighereducation. com/world-university-rankings/2018/world-ranking\#!/page/0/length/25/sort_by/rank/sort_ order/asc/cols/stats. Accessed 3 June 2019.

${ }^{2}$ In this article, "public research universities in Japan" refer to the top Japanese national research universities. Most public municipal universities in Japan do not meet the criteria of doctoral research universities according to the Carnegie Classification in the USA, and less than 20 national universities fit this classification (Mitsuda 2004).
} 
Japanese and the US public research universities have different outcomes in terms of donation trends. Unlike Japan, USA has a long history of donating generously to universities (Drezner 2011). The total donations to the US public research universities have increased rapidly since the 1980s and are now the highest worldwide (Fukui 2018). When examining the statistics of donations per enrollment, the top American public research university - the University of California Los Angeles-received \$12,257 per enrollment in 2016-2017. This is approximately 2.6 times the $\$ 4681$ received by the University of Tokyo per enrollment in 20162017. ${ }^{3}$ More importantly, although donations to public research universities in both countries dropped during the 2008 economic recession, top US research universities recovered by the late 2010s, while Japanese public research universities experienced a decrease in donations revenue during the same period (see Data and methods).

However, since the mid-2000s, both countries' public research universities have been placed in similar environmental situations for attracting donations. According to Liu (2006), the following two main environmental factors affect public research universities' donations: macroeconomic and government policy factors. Regarding macroeconomic factors, both countries experienced the 2008 economic recession, but their capital markets recovered by the late 2010s (Zhang 2018). Second, both countries' public research universities have experienced decreased government appropriations and are expected to fundraise more (Jackson 2013; Onishi 2007). Third, both governments apply similar charitable deduction policies to encourage donations to higher education. American universities are classified as "public charities" under Internal Revenue Code 509(a)(1), and monetary donations to this organizational type can be deducted from donors' taxable income. Similarly, donors can deduct monetary donations to Japanese public universities from their taxable income. ${ }^{4}$ However, the Japanese government has given donors fewer incentives to donate stocks, land, or real estate and has discouraged universities from keeping them (see Literature review and theoretical framework).

Therefore, from the mid-2000s to the late 2010s, trends in donations to Japanese and US public research universities have contrasted (different outcomes) even under similar macroeconomic and government policy situations (similar system), such as economic recovery, decreasing public funds, increasing institutional fundraising, and similar charitable deduction systems (except for property gifts). Therefore, identifying the factors that influence macrodonation trends for Japanese and the US public research universities aids understanding of how government public policy and economic factors differentially affect higher education donation behaviors.

The first research question examines whether capital market trends affect donation revenue of public research universities operating under Japanese and American tax systems. Macro trends in

\footnotetext{
${ }_{3}^{3}$ Donation amounts are calculated at a rate of 110 yen per dollar. Estimates used data from Japanese national universities' 2016-2017 financial statements and annual reports, and from Kaplan (2018).

${ }^{4}$ Charitable deductions for cash cannot exceed $50 \%$ of adjusted gross income in the USA and $40 \%$ of total income in Japan. The Japanese Tax Reform of 2016 allowed donations to support students of national university corporations as a tax credit item, so donors could take tax credits beginning in 2016. Since it is too early to look at the effect of this tax reform, and because this article mainly focuses on the differences of charitable deductions for appreciated property gifts between the USA and Japan, this study looks at the trends in donations and tax policies before this tax reform.
} 
American higher education institutions' donations are strongly correlated with stock prices (Bristol 1992; Clotfelter 2003; Drezner 2007; Leslie et al. 1983; Smith and Ehrenberg 2003). These studies used stock prices as indicators of social wealth, and some researchers have deduced that potential donors make more donations as their wealth increases (Kaplan 2018). However, there may be another link between stock prices and donations: under a given tax policy, stock prices affect the "price of giving" (Clotfelter 2003; Fukui 2012), which is the net cost to donors after consideration of the tax benefits. When the effect of stock prices was considered, studies tended to focus only on the wealth effect; the tax policy perspective, however, is required to better understand why stock prices influence higher education donations. The main challenge researchers faced in verifying this theory was in observing the price of giving effect for appreciated property gifts when examining only one country. This paper addresses that challenge by comparing the different charitable deduction structures for appreciated property gifts in Japan and USA. Moreover, stock prices theoretically have the opposite effect on the price of giving (i.e., the net cost of donations) in the two countries. An increase in stock prices increases donations under the US tax structure but decreases donations under the Japanese tax structure. Thus, clarifying the effect of stock market prices on higher education donations under particular tax policies will help explain different donation trends in Japan and the USA.

The second research question concerns how the level of government support for higher education affects donations to both countries' public research universities. A number of articles have attempted to clarify the relationship between government funding and the donation revenues of universities, finding that government appropriations have a crowding-in effect on university donations (Cheslock and Gianneschi 2008; Marudas and Jacobs 2004; Payne 2001), while others have observed a crowding-out effect (Leslie and Ramey 1988; Liu 2006). The experimental results are controversial, and little is currently known about the decreasing trends in government funding to induce or reduce public research universities' donations in countries other than the USA, despite the constraints on government funding to public research universities being a global trend (OECD 2007). In this context, clarifying the impact of government funding on donors' behavior from a comparative perspective is essential in higher education research. This study provides new insight into whether the decreasing trends in government appropriations from the mid-2000s to the late 2010s affected the USA and Japanese public research universities' donations differently.

\section{Literature review and theoretical framework}

\section{Donations and higher education}

A donation is defined as a "voluntary gift made with no expectation of benefit" (Lister 2013, p. 19); it is used almost interchangeably with charitable giving or gifts, which can be defined as "the donation of money to an organization that benefits others beyond one's own family" (Bekkers and Wiepking 2011, p. 925). Donations are essential resources for private and public universities in the USA. They enable universities to make new investments, such as developing educational courses (McClure 2015), enhancing academic research (Ohman et al. 2016), providing student financial aid (Gaudiani 2004), and strengthening athletic programs (Walker 2015).

Although American private universities have a long history of fundraising activities, in the latter half of the twentieth century, public universities also began requesting gifts to compensate declining state funding (Drezner 2011). The National Association of State Universities 
and Land Grant Colleges (1966) stated that public universities received only $15 \%$ of the total gifts to higher education in 1965 and revealed that public universities must focus more on donation revenue if future state funding decreases. Since the 1970s, fundraising has become a professional activity and one of university presidents' most important tasks (Cook 1997). As several prestigious US public universities focused more on fundraising due to declining state funding, they received 47\% of the total gifts in higher education in 2017 (Kaplan 2018).

Asian countries' policymakers and university managers have increased donation expectations for public research universities (Drezner 2019; Rohayati et al. 2016; Sung 2016). Drezner (2019) explained this phenomenon by highlighting three trends. First, tax revenue alone has become insufficient to support publicly funded universities, placing them in need of donations. Second, the international comparison and global rankings of universities strengthen American universities' isomorphism and their interest in obtaining more financial resources. Third, universities tend to adopt university management's best practices, and several countries' universities have adopted successful American universities' fundraising models. However, research on higher education donations outside the Western context is inadequate (Rohayati et al. 2016), and it is unknown whether adopting American fundraising models will be successful (Drezner 2019). In many countries other than the USA, higher education receives less support from private donors than other nonprofit organizations, such as churches, because people perceive the government as being responsible for supporting higher education (Johnstone et al. 1998). Moreover, successful fundraising requires favorable tax treatments for charitable donations, and different tax structures may affect different donating behaviors toward universities (Johnstone et al. 1998; Rohayati et al. 2016).

Although some studies have focused on the influence of environmental factors on donations, including macroeconomic factors (Clotfelter 2003; Coughlin and Erekson 1986; Drezner 2007; Smith and Ehrenberg 2003), government appropriations (Cheslock and Gianneschi 2008; Leslie and Ramey 1988; Liu 2006; Marudas and Jacobs 2004; Payne 2001), and tax policies (Clotfelter 2003; Drezner 2007; Duquette 2016; Holmes 2009), few have investigated environmental factors' impact on universities' donations through an international comparative perspective. Thus, Drezner (2019) reveals that answers to research questions, such as how different tax structures in different countries motivate donors and whether donors in different countries can be motivated to give in a similar way, are still unknown. Given that constraints on government funding to public research universities are a global trend, clarifying tax policies' and government funding's impact on donors' behavior from a comparative perspective is essential.

\section{How do capital markets and tax policies affect donations to public research universities?}

One of the influential factors concerning donations is donor wealth. The "wealth effect," which suggests people donate to charitable causes when they accumulate more assets, can explain this (Havens et al. 2006; Wiepking and Bekkers 2012). Many empirical studies point out that high-income graduates tend to actively donate to universities (e.g., Holmes 2009; Monks 2003; Okunade et al. 1994; Skari 2014). Similarly, higher education donations increase when the macroeconomic situation improves (i.e., rising stock prices and per capita income; e.g., Clotfelter 2003; Coughlin and Erekson 1986; Drezner 2007; Liu 2006; Smith and Ehrenberg 2003). Stock prices, in particular, are one of the most influential variables correlated with US higher education donations (Kaplan 2018). Panel data from private research universities from 1968-69 to 1998-1999 showed that stock prices had a positive effect on donations (Smith and 
Ehrenberg 2003). These previous studies used the wealth effect to imply that higher education donations increase when the economy improves and individuals' capacity to make contributions increases (Kaplan 2018).

Increasing stock prices' effect on higher education donations can be explained not only by the wealth effect but also by the concept of the price of giving (Andreoni 2006; Clotfelter 2003). In general, if the tax system benefits donors (i.e., donations deducted from income tax), we can consider that the government pays a portion of the donation cost. For example, if a $\$ 1$ higher education donation provides the donor with a $\$ 0.20$ tax benefit, then the net cost to that donor is only $\$ 0.80$. Theoretically, the greater the decrease in the price of giving, the greater the incentive for donations. The critical point here is that donors' costs depend on their country's tax structure and specific tax benefits for donors. Compared with the Japanese national tax system, the US federal tax system provides unique tax benefits for donations of appreciated properties such as stocks, land, or real estate to American universities (Fukui 2018). US donors in this situation gain the following tax benefits: first, they can deduct these appreciated property gifts' fair market value from their taxable income, and second, they are exempt from paying capital gains tax (Andreoni 2006). Under this tax policy, the price of giving can be generalized with the following formula:

$$
\text { priceof giving }_{U S}=1-t_{i}-t_{c} *\left(1-\frac{b}{f}\right)=1-t_{i}-t_{c}+t_{c} * \frac{b}{f} \ldots
$$

in which $t_{\mathrm{i}}$ is the income tax rate, $t_{\mathrm{c}}$ is the capital gains tax rate, $b$ is the acquisition price of the stock, and $f$ is the fair market value of the stock. Formula (1) implies that the more stock prices increase, the more the price of giving decreases in the USA. To put these tax policies in perspective, consider the example of donors who donate a stock for which the acquisition price was $\$ 100$, and its fair market value is $\$ 1000$. These donors could deduct the appreciated property gifts' fair market value from their taxable income, so that the $\$ 1000$ is multiplied by the income tax rate of $39.6 \%$, totaling $\$ 396$ to be deducted from their income tax. Donors are also exempt from paying capital gains tax, so the $\$ 900$ capital gains are multiplied by their $20 \%$ tax rate, totaling $\$ 180$ exempted from the capital gains tax. The $\$ 576$ deduction can be considered an indirect government subsidy. The actual price of giving is 0.424 , meaning donors pay only $42.4 \%$ of their donation amount. As Table 1 shows, increased stock prices decrease the price of giving under the US tax structure. Therefore, increasing stock prices have a direct effect on the tax benefits for donors of appreciated stocks under the US tax structure.

Table 1 Relationship between stock prices and the price of giving under the US Federal Tax and Japanese Tax Policies, for a donation of stock acquired for $\$ 100$

\begin{tabular}{lll}
\hline Stock price & Price of giving (USA) & Price of giving (Japan) \\
\hline$\$ 100$ & 0.604 & 0.550 \\
$\$ 300$ & 0.471 & 0.717 \\
$\$ 500$ & 0.444 & 0.750 \\
$\$ 700$ & 0.433 & 0.764 \\
$\$ 1000$ & 0.424 & 0.775 \\
\hline
\end{tabular}

The price of giving is the net cost to donors after consideration of the tax benefits. For example, for stock prices under $\$ 1000$, donors pay only $42.4 \%$ of the donation amount in the USA; however, donors pay $77.5 \%$ of the donation amount in Japan. The price of giving in the USA and Japan are estimated based on each country's highest tax rates in 2015-2016. Thus, the price of giving (USA) was estimated assuming an income tax rate of $39.6 \%$ and a capital gains tax rate of $20 \%$. The price of giving (Japan) was estimated assuming an income tax rate of $45.0 \%$ and a capital gains tax rate of $20 \%$ 
Previous studies that show the correlation between stock prices and higher education donations have tended to refer to the wealth effect rather than the tax incentives' effect (e.g., Bristol 1992; Kaplan 2018; Leslie et al. 1983; Smith and Ehrenberg 2003). Too little attention has been paid to how this US tax structure affects the relationship between stock prices and donations. One reason for this may be researchers' difficulty in observing the price of giving effect for appreciated property gifts (Andreoni 2006) when examining only one country. To overcome this issue, this study verified the theory through a comparison with the Japanese tax structure, because stock prices theoretically have the opposite effect on the price of giving under the Japanese tax structure. The USA and Japan have huge differences in tax incentives regarding stock donations. ${ }^{5}$ When donors' gift appreciated property to Japanese universities, they are exempt from capital gains tax, ${ }^{6}$ but they may only deduct the stocks' acquisition value from their taxable income. ${ }^{7}$ Formula (2) shows the generalized price of donating appreciated property under the Japanese tax structure.

$$
\text { price of giving }_{J A P A N}=1-\frac{b}{f} * t_{i}-t_{c} *\left(1-\frac{b}{f}\right)=1-\frac{b}{f}\left(t_{i}-t_{c}\right)-t_{c} \cdots
$$

Regarding the second term in Formula (2), when the income tax rate is higher than the capital gains tax rate, rising stock values increase the price of giving and disincentivize donating (historically, the Japanese income tax rate is higher than the capital gains tax rate). In this case, as in the American federal tax structure, when donors donate stock for which the acquisition price was $\$ 100$ and the fair market value is $\$ 1000$, they are exempt from paying capital gains tax; the capital gains of $\$ 900$ are multiplied by the capital gains tax rate of $20 \%$, equaling $\$ 180$ is tax exempt. However, donors can only deduct the acquisition price of appreciated property gifts from their taxable income, so the $\$ 100$ acquisition price is multiplied by the income tax rate of $45 \%$, totaling $\$ 45$ that can be deducted. Accordingly, the indirect government subsidy is only $\$ 225$. The resulting actual price of giving is 0.775 , meaning donors pay $77.5 \%$ of the donation amount. Unlike the American tax system, the more stock prices increase in Japan, the

\footnotetext{
${ }^{5}$ Under the Japanese tax structure, there are two methods for filing tax returns: tax deductions that reduce the amount of taxable income, and tax credits that directly decrease the amount of tax (see Okuyama and Yamauchi 2015). In the case of donations to Japanese national universities, individual donors could choose tax deductions before April 2017. According to this tax deduction method, when Japanese donors give cash, they could deduct their total donations minus 2000 yen from their taxable income. Although total deductions are limited to $40 \%$ of gross income and excess donation amounts cannot be transferred to the next tax return, the Japanese government allows donations' deduction from taxable income, similar to the US tax structure. In 2011, the Japanese government allowed donors to choose between tax deductions and tax credits (Okuyama and Yamauchi 2015), but national universities' donations were exempted from this tax reform. In 2016, the Japanese government reformed the Act on Special Measures Concerning Taxation, in which the government allowed national university corporations' donors to choose between tax deductions and tax credit items only if the purpose was providing student support. This tax reform will affect future donations to national universities. However, since it is too early to look at the tax reform's effect and this paper focuses on the differences of charitable deductions for appreciated property gifts between the USA and Japan, the empirical analysis used data before the reform.

${ }^{6}$ Act on Special Measures Concerning Taxation Article 40.

${ }^{7}$ Act on Special Measures Concerning Taxation Article 40-19.
} 
more the price of giving increases (Table 1). In addition, the Japanese government has allowed national universities to invest only assets with guaranteed principal, ${ }^{8}$ and until 2017 had not incentivized national universities' stockholding. As a result, Japanese national universities have only been able to operate financial instruments with risk-free assets and therefore sold stocks in exchange for cash even after receiving them from donors. ${ }^{9}$ Accordingly, Japanese national universities have rarely received stock donations.

Therefore, this paper hypothesizes that stock prices positively correlate with donations to public research universities in the USA, but not with donations to national universities in Japan because of the Japanese tax structure.

\section{How do government appropriations affect donations to public research universities?}

The government may affect donor behavior not only through tax structures as described above but also through financial policies. Research into the relationship between government funding and donor behavior has a long history in economics (Roberts 1984; Warr 1982) and has included the effect of government appropriations on higher education donations (Cheslock and Gianneschi 2008; Leslie and Ramey 1988; Liu 2006; Marudas and Jacobs 2004; Payne 2001).

The classical theory of government funding's crowding-out effect on donations indicates that if primary donor interest concerns the increase in total provision of public goods in a society, then donors determine their donations based on the total amount of public goods (Roberts 1984; Warr 1982). Based on this model, when government funding and private resources are substituted for each other, government fundings to non-profit organizations crowd-out donations completely. Some empirical research has shown that government appropriations have a crowding-out effect on universities' donations, meaning the amount of higher education donations decreases when universities are sufficiently funded by the government (Leslie and Ramey 1988; Liu 2006). This can also be explained from the universities' perspective, as considerable government funding discourages universities from organizing fundraisers, resulting in decreased donations (Andreoni and Payne 2003).

In contrast, government funding may also produce a crowding-in effect, meaning that donors increase universities' donations when more government funding is provided (Cheslock and Gianneschi 2008; Marudas and Jacobs 2004; Payne 2001). This crowding-in model assumes the information asymmetry between donors and universities, and the government funding levels become an endorsement of the universities' quality or social need (Lu 2016; Rose-Ackerman 1986). Several empirical studies support this theory, such as Cheslock and Gianneschi's (2008) panel analysis of public universities' donations and state appropriations data from 1994 to 2004. This work showed that donations slightly decreased in the USA when state appropriations decreased. Using longitudinal data of donations to research universities and federal research grants from 1972 to 1997, Payne (2001) found a positive relationship between donations and federal research grants for US research universities.

${ }^{8}$ Act of General Rules for Incorporated Administrative Agencies Article 47 (Investment of Surplus Funds).

${ }_{9}^{9}$ In 2017, the ministry issued the "Rules regarding acquisition of stocks and share options by National university corporation and Inter-university research corporation" and allowed national universities to retain stocks under certain conditions. The document is available at http://www.mext.go.jp/a_menu/koutou/houjin/_icsFiles/afieldfile/2017/08/02 /1222251_04_1.pdf. Accessed 3 June 2019. 
However, Lu's (2016) meta-analysis suggests that there is almost no correlation between government funding and private donations, implying that the crowding-in and crowding-out effects offset each other. Another explanation is Andreoni's (1989) "warm glow" theory, which posits that if donors are satisfied with their giving behavior, donations become their private good. Accordingly, government funding may not completely crowd out donations.

The results are still controversial, and most studies related to this topic use data from before the early 2000s. In addition, there has been no detailed investigation into whether decreasing trends in government funding induce or reduce donations to Asian public research universities, which have historically relied on government funding. To fill this gap, this paper examines how government support levels for higher education affect donations to American and Japanese public research universities using panel data from the mid-2000s to the late 2010 s.

\section{Data and methods}

When international comparative researchers select samples from different countries, they confront the sampling trade-off between within-country representativeness and betweencountry comparability (Reynolds et al. 2003). Between-country comparability can be achieved by selecting homogeneous samples. However, these samples have been criticized as being subgroups of national populations that are not representative of all national populations. The balance between the two depends on the type of research. In the case of "theoretical international research," which examines the cross-national generalizability of a model, like this study, comparability is important (Reynolds et al. 2003). ${ }^{10}$ For example, if a study chose samples with different characteristics (e.g., high-prestige universities from Japan and low-prestige universities from the USA), it would become difficult to clarify whether observed result differences were derived from "true" country differences or simply from sample differences (Reynolds et al. 2003; van de Vijver and Leung, 1997). Accordingly, this study selected top-tier public research universities from each country based on respective university classification because institution type and prestige affect donor behavior (Stephenson and Bell 2014).

American institutions were chosen from doctoral public research universities listed in the Carnegie Classification and which included data from 2007-2008 to 2015-2016 for all variables available. The Carnegie Classification is associated with prestigious factors, such as selectivity or the amount of institutions' federal research grants (Morphew and Baker 2004). While there is no clear classification of top research universities in Japan, in 2014, the Japanese government introduced the concept of "super global universities type A," which has the potential to be ranked among the top 100 world universities (Hashimoto 2017). Additionally, in 2016, the government defined "global leading universities" to encourage improved education and research in academia (Sunami 2017). Seventeen national universities have been classified into either category and are expected to compete with world-class universities. ${ }^{11}$ Japanese public research universities were chosen for this study based on their designation in either category. As a result, this study used donation panel data from 2007-2008 to 2015-2016 for 17 Japanese national universities, as well as

\footnotetext{
${ }^{10}$ If the research type is "descriptive/contextual international research," which examines attitudes and behaviors within specific countries, within-country representativeness is important (Reynolds et al. 2003).

${ }^{11}$ Only two private universities were selected as super global universities type A; no public municipal universities have achieved this classification.
} 
104 American doctoral public research universities, according to the 2007-2008 to 2015-2016 Carnegie Classification. The data period was derived from the accounting donations' definition in the Japanese national universities' financial statements. Due to a change in Japanese national universities' accounting standards in 2007-2008 to include property gifts contributed by faculty members and obtained using faculty research grants as donations, the consistency of donation data prior to 2007-2008 cannot be verified.

The dependent variables were as follows: (1) total donations to Japanese public research universities, based on universities' financial statements, and (2) total donations to US public research universities, derived from the Council for Aid to Education VSE Survey and Data Miner. ${ }^{12}$ The independent variables were as follows: (1) stock prices from the annual average of the Nikkei Stock Price Index from April to March for Japan, and (2) the annual average of the Standard \& Poor's 500 Index from June to July for the USA. To control for societal wealth's effect, this model used prefecture average per capita income derived from the Japanese Cabinet Office ${ }^{13}$ for Japanese universities, and state per capita income derived from the US Bureau of Economic Analysis ${ }^{14}$ for American universities.

Especially for research universities, government operating grants as well as government research grants and contracts are essential resources to support research. To estimate government grants' effects on US donations, state appropriations and federal grants and contracts awarded to public research universities were derived from the Integrated Postsecondary Education Data System. ${ }^{15}$ Much of Japanese national universities' current expenses are financed by government operating grants called Uneihi Kouhukin, which are mainly based on students and staff numbers. There are also competitive government research grants and contracts. To estimate government grants' effects on Japanese donations, both management operating grants for national university corporations (Uneihi Kouhukin) and competitive government research grants and contracts were considered. ${ }^{16}$ This information was derived from datasets created from the Japanese national universities' annual financial statements. To

${ }^{12}$ US data were retrieved from https://cae.org/vse-data-miner/. Accessed 8 April 2018. The Japanese data defined donations as money or properties gifted to the university to encourage or support academic research, education/research, or other activities, or gifted as financial resources for scholarship or student loans (The University of Tokyo 2004). The US data defined donations as the sum of outright support for current operations and for capital purposes and deferred giving, which were donated by alumni, parents, other individuals, foundations, corporations, and others (Kaplan 2018).

${ }^{13}$ Data were retrieved from the Japanese Cabinet Office, https://www.esri.cao.go. jp/jp/sna/data/data_list/kenmin/files/contents/main_h27.html. Accessed 3 June 2019.

${ }_{14}^{14}$ Data were retrieved from the US Bureau of Economic Analysis, https://www.bea.gov/. Accessed 3 June 2019.

${ }^{15}$ Data were retrieved from the US Department of Education, National Center for Education Statistics, Integrated Postsecondary Education Data System (IPEDS), Finance, https://nces.ed. gov/ipeds/use-the-data, Accessed 3 June 2019.

${ }^{16}$ Management operating grants in Japanese cash flow statements included national universities' succession staff's retirement benefits before being incorporated into national university corporations in 2004. To estimate the effect of government appropriations only for current operations, this model used a variable that excluded these retirement benefits. The Japanese government research grants and contracts were calculated as the total research grants ("Kagaku-Kenkyuhi-Hojokin") and research contracts (“Jutaku-Kenkyu”). 
Table 2 Descriptive statistics for the sample

Mean S.D. Min Max

Panel US public research universities

Dependent variable

Donations (thousands of dollars)

Independent variables

State appropriations (thousands of dollars)

Federal research funding (thousands of dollars)

US stock prices (Standard \& Poor's 500 Index)

US state per capita income (thousands of dollars)

No. of observations

No. of institutions

Panel Japanese national research universities

Dependent variable

Donations (thousands of dollars)

Independent variables

Management operating grants (thousands of dollars)

Government research grants (thousands of dollars)

Japan stock prices (Nikkei Stock Price Index)

Japan prefecture per capita income (thousands of dollars)

No. of observations

No. of institutions

$\begin{array}{llll}76,710 & 83,429 & 1336 & 486,412 \\ 191,033 & 120,636 & 25,583 & 693,461 \\ 137,514 & 165,323 & 233 & 1,067,960 \\ 1406 & 289 & 974 & 1833 \\ 40 & 6 & 30 & 62\end{array}$

936

104

$\begin{array}{llll}41,839 & 37,726 & 4930 & 187,086 \\ 271,249 & 174,605 & 44,849 & 772,088 \\ 121,136 & 124,005 & 5743 & 532,632 \\ 12,626 & 3233 & 9278 & 18,160 \\ 32 & 10 & 22 & 53\end{array}$

153

17

All data in the USA were converted to 2010 constant dollars using the Higher Education Price Index (HEPI). All data in Japan were converted to 2010 constant dollars using the Japanese Consumer Price Index (all items, less fresh food). Japanese donations, management operating grants, government research grants, and Japan prefecture per capita income are calculated at a rate of 110 yen per dollar

verify whether government funds have a crowding-out effect on donations, the previous year's government funds' impact was also estimated. ${ }^{17}$ As the panel data from both USA and Japanese represent 9 years of data, the number of observations for the US and Japanese public research universities becomes $936(104 \times 9$ years $)$ and $153(17 \times 9$ years $)$, respectively (Table 2). On average, Japanese public research universities received more governmental management operating grants $(\$ 271,249)$ than US public research universities' state appropriations $(\$ 191,033)$ and obtained fewer donations $(\$ 41,839$ and $\$ 76,710$, respectively) in this sample.

To control for observed and unobserved traits in states, prefectures, and universities, the models were estimated with a university-fixed effects model. All variables were transformed into 2010 constant prices and incorporated into a logarithm for estimation. Additionally, because the models had heteroskedasticity, we used robust standard errors for estimation. The basic regression equation estimated for American public research universities is as follows:

$$
\begin{aligned}
{\ln U S \_D_{i t}=} & \beta_{0}+\beta_{1} \text { lnUS_G_grants }_{i t-1}+\beta_{2} \text { lnUS_G_research }_{i t-1}+\beta_{3}{\ln U S S_{-} S_{\text {Stock }}}_{t} \\
& +\beta_{4} \text { lnUS_lncome }_{s t}+X_{i}+v_{i t}
\end{aligned}
$$

where $U S_{-} D_{i t}$ is the total American research university's donations $i$ in year $t, U S_{-} G_{-}$

\footnotetext{
${ }^{17}$ To estimate government funding's effect on donations, Cheslock and Gianneschi (2008) used the previous year's state appropriations, but Payne (2001) used the current year's federal research grants. This study also shows the estimation by using the current year's government funding.
} 
Table 3 A total of 104 American public research universities: average donations, government funds, and economic indicators per institution per year

\begin{tabular}{llllll}
\hline Year & $\begin{array}{l}\text { Donations } \\
\text { (thousands } \\
\text { of dollars) }\end{array}$ & $\begin{array}{l}\text { State } \\
\text { appropriations } \\
\text { (thousands of } \\
\text { dollars) }\end{array}$ & $\begin{array}{l}\text { Federal research } \\
\text { grants (thousands } \\
\text { of dollars) }\end{array}$ & $\begin{array}{l}\text { State's average per } \\
\text { capita income } \\
\text { (thousands of dollars) }\end{array}$ & $\begin{array}{l}\text { Stock prices } \\
\text { (Standard \& } \\
\text { Poor's 500 } \\
\text { Index) }\end{array}$ \\
\hline $2007-2008$ & 77,704 & 227,486 & 130,701 & 39 & 1472 \\
$2008-2009$ & 69,437 & 209,477 & 133,558 & 40 & 974 \\
$2009-2010$ & 68,179 & 196,837 & 142,744 & 38 & 1086 \\
$2010-2011$ & 71,744 & 192,815 & 148,949 & 38 & 1202 \\
$2011-2012$ & 74,484 & 175,444 & 145,827 & 40 & 1238 \\
$2012-2013$ & 77,111 & 173,629 & 141,673 & 41 & 1406 \\
$2013-2014$ & 81,709 & 180,392 & 133,336 & 40 & 1649 \\
$2014-2015$ & 83,377 & 181,283 & 130,326 & 41 & 1789 \\
$2015-2016$ & 86,644 & 181,936 & 130,514 & 41 & $21.6 \%$ \\
Total change & $11.5 \%$ & $-20.0 \%$ & $-0.1 \%$ & $5.1 \%$ & \\
(2007-2008 & & & & & \\
to & & & & & \\
$2015-2016)$ & & & & & \\
\hline
\end{tabular}

All data were converted to 2010 constant dollars using the Higher Education Price Index (HEPI).

grants $_{i t-1}$ is the American research university's state appropriations $i$ in year $t-1, U S S_{-}$ research $_{i t-1}$ is the American research university's federal research grants and contracts $i$ in year $t-1, U S_{-} S_{\text {Stock }}$ is the yearly average of Standard and Poor's 500 Index from June to July, and US_Income $s t$ is per capita income of state $s$ where the university is located in year $t$. $X_{i}$ is observed and unobserved fixed effects of university $i$. The regression equation estimated

Table 4 A total of 17 Japanese national universities: average donations, government funds, and economic indicators per institution per year

\begin{tabular}{llllll}
\hline Year & $\begin{array}{l}\text { Donations } \\
\text { (thousands } \\
\text { of dollars) }\end{array}$ & $\begin{array}{l}\text { Management expense } \\
\text { grants } \\
\text { (Uneihikouhukin) } \\
\text { (thousands of dollars) }\end{array}$ & $\begin{array}{l}\text { Government } \\
\text { research grants and } \\
\text { contracts (thousands } \\
\text { of dollars) }\end{array}$ & $\begin{array}{l}\text { Prefecture's } \\
\text { average per capita } \\
\text { income (thousands } \\
\text { of dollars) }\end{array}$ & $\begin{array}{l}\text { Stock prices } \\
\text { (per Nikkei } \\
\text { Stock Price } \\
\text { Index) }\end{array}$ \\
\hline $2007-2008$ & 47,697 & 281,262 & 117,306 & 35 & 15,744 \\
$2008-2009$ & 46,822 & 274,030 & 11,244 & 32 & 10,490 \\
$2009-2010$ & 42,554 & 273,795 & 114,867 & 30 & 9960 \\
$2010-2011$ & 41,554 & 279,818 & 121,043 & 31 & 9827 \\
$2011-2012$ & 42,052 & 286,759 & 118,790 & 31 & 9799 \\
$2012-2013$ & 41,892 & 272,104 & 122,982 & 31 & 14,400 \\
$2013-2014$ & 41,586 & 259,311 & 129,288 & 32 & 15,981 \\
$2014-2015$ & 35,769 & 258,091 & 126,942 & 31 & 18,160 \\
$2015-2016$ & 36,626 & 256,069 & 127,761 & 32 & $-6.4 \%$ \\
Total change & $-23.2 \%$ & $-9.0 \%$ & $8.9 \%$ & & \\
$\quad(2007-2008$ & & & & & \\
to & & & & & \\
2015-2016) & & & & & \\
\hline
\end{tabular}

All data were converted to 2010 constant dollars using the Japanese Consumer Price Index (all items, less fresh food). Donations, management expense grants, government research grants, and prefecture's per capita income are calculated at a rate of 110 yen per dollar 
for Japanese national universities is as follows:

$$
\begin{aligned}
\text { lnJP_D }_{i t}= & \beta_{0}+\beta_{1} \text { lnJP_G_grants }_{i t-1}+\beta_{2} \text { lnJP_G_research }_{i t-1}+\beta_{3} \text { InJP_Stock }_{t} \\
& +\beta_{4} \text { lnJP_Income }_{p t}+X_{i}+v_{i t}
\end{aligned}
$$

where $J P_{-} D_{i t}$ is total donations to a Japanese national university $i$ in year $t, J P{ }_{-} G_{-}$grants st $_{\text {- }}$ ${ }_{1}$ is a Japanese national university's government management operating grants $i$ in year $t-1$, $J P_{-} G_{-}$research $_{i t-1}$ is a Japanese national university's government research grants and contracts $i$ in year $t-1, J P{ }_{-}$Stock $_{t}$ is the yearly average of the Nikkei Stock price index from April to March, and $J P_{-}$Income $_{p t}$ is per capita income of prefecture $p$ where the university is located in year $t$.

Tables 3 and 4 depict the average level of donations, government appropriations, research grants, and economic indicators by year for the American and Japanese institutions' sample in 2010 constant dollars, respectively. Average American public research universities' donations fell slightly in 2008-2009 when the global financial crisis occurred (Table 3). However, after the economic recession, average donations gradually grew and reached $\$ 86.6$ million in 2015$2016,11.5 \%$ higher than in 2007-2008. State appropriations also dropped in 2008-2009 and indicated a decreasing trend; accordingly, average state appropriations in 2015-2016 were $20.0 \%$ lower than in 2007-2008. Conversely, federal research grants were almost stable from 2007-2008 to 2015-2016. Average stock prices dropped dramatically during the global financial crisis in 2008-2009 but began rising in 2009-2010.

In contrast, Table 4 shows that the 17 Japanese national universities' average donations gradually decreased; the average donation amount in 2015-2016 was $23.2 \%$ less than in 20072008. Japanese government management operating grants gradually decreased by $9.0 \%$ from 2007-2008 to 2015-2016. Conversely, average government research grants increased by $8.9 \%$ from 2007-2008 to 2015-2016 because of recent policies encouraging competitive funds in Japanese higher education. Prefectures' average per capita income trends were stagnant after the financial crisis in 2008-2009. Average stock prices performed similarly for American states after the 2008 global financial crisis when stock prices dropped. Additionally, stock prices fell further after the 2011 Great East Japan Earthquake. After the Liberal Democratic Party was reappointed and launched, the "Abenomics" economic policy (named after the Japanese Prime Minister Shinzo Abe), which spurred monetary easing and increased money supply in 2012-2013, stock prices gradually increased.

\section{Results}

Table 5 shows the regression results for American public research universities' donations from 2007-2008 to 2015-2016. Models 1 and 2 present pooled OLS estimates without universityfixed effects. The pooled OLS estimates show that stock price, state appropriations, and federal grants and contracts all have positive effects on donations to US universities. Model 2 shows that, on average, each $1 \%$ change in stock prices is associated with a $0.58 \%$ increase in public research universities' donations, and each $1 \%$ state appropriations or federal research grants increase is associated with a $0.60 \%$ and $0.45 \%$ donation increase, respectively. The average state per capita income, used as a control variable, did not support our assumptions in Models 1 and 2. It showed that universities located in states with lower average per capita income 
Table 5 Natural logarithm difference of donations to 104 American public research universities, 2007-2008 to 2015-2016

\begin{tabular}{lllll}
\hline & $\begin{array}{l}\text { Pooled OLS } \\
\text { Model 1 }\end{array}$ & $\begin{array}{l}\text { Pooled OLS } \\
\text { Model 2 }\end{array}$ & $\begin{array}{l}\text { Fixed effect } \\
\text { Model 3 }\end{array}$ & $\begin{array}{l}\text { Fixed effect } \\
\text { Model 4 }\end{array}$ \\
\hline State government appropriations (t) & $\begin{array}{l}0.602 * * * \\
(0.0783)\end{array}$ & & -0.0365 & $(0.0509)$ \\
Federal research grants and contracts (t) & $\begin{array}{l}0.435^{* * *} \\
\text { (0.0519) }\end{array}$ & & 0.0350 & $(0.0556)$ \\
State government & & $0.602 * * *$ & & -0.0829 \\
appropriations (t-1) & & $(0.0789)$ & & $(0.0624)$ \\
Federal research grants and contracts (t-1) & & $0.446 * * *$ & & 0.0398 \\
& & $(0.0528)$ & & $(0.0414)$ \\
Stock & $0.529 * * *$ & $0.576^{* * *}$ & $0.209 * * *$ & $0.182 * * *$ \\
& $(0.114)$ & $(0.114)$ & $(0.0557)$ & $(0.0575)$ \\
Income & $-1.001 * * *$ & $-0.974 * * *$ & $0.956 * * *$ & $0.990^{* * *}$ \\
Constant & $(0.168)$ & $(0.166)$ & $(0.368)$ & $(0.363)$ \\
& $5.143 * *$ & $4.326 *$ & 6.042 & $6.655^{*}$ \\
University-fixed & $(2.202)$ & $(2.247)$ & $(4.037)$ & $(3.875)$ \\
Observations & No & No & Yes & Yes \\
R-squared & 936 & 936 & 936 & 936 \\
Number of universities & 0.592 & 0.602 & 0.070 & 0.072
\end{tabular}

Robust standard errors in parentheses

$* * * p<0.01, * * p<0.05, * p<0.1$

The within R-squared is reported for the fixed-effects models

tended to get more donations, which is consistent with the results of pooled OLS estimates in Cheslock and Gianneschi (2008).

Models 3 and 4 added university-fixed effects to the regressions to control for observed and unobserved institutional traits. These parameter estimates are identified in within-university changes over time. Since R-squared (within) is 0.07 , these models cannot be used to predict the trends of donations to public research universities themselves; however, it is worth examining each variable's effect on donations. In these models, although the stock prices' effect decreased from 0.58 to $0.18 \%$ (Model 4 ), stock prices retained a statistically positive effect on donations. However, the results suggest that the government appropriations and research grants to universities have no effect on donations in the USA, when controlling for university-fixed effects (Models 3 and 4). Furthermore, once university effects were controlled for, the coefficient of state per capita income became significantly positive. On average, a $1 \%$ change in state per capita income is associated with $0.99 \%$ increase in public research universities' donations in the USA (Model 4). This indicates that American public research universities' donations increase when the university's state economic health improves.

In contrast, the regression results for Japanese national universities' donations from 20072008 to 2015-2016 in Table 6 indicate that stock prices do not have a positive effect on their donations (Models 5 to 8). All coefficients of stock prices are negative but insignificant without Model 7. Unlike in the USA, the coefficient of prefectures' per capita income has no statistically positive effect on donations.

Regarding the effect of Japan's government funding, the pooled OLS estimation (Models 5 and 6) suggests that institutions receiving large grants tend to receive larger donations. On average, each $1 \%$ management operating grants' increase is associated with a $0.44 \%$ donations' increase, and each $1 \%$ research grants' increase is associated with a $0.46 \%$ donations' 
Table 6 Natural logarithm difference of donations to 17 Japanese national research universities, 2007-2008 to 2015-2016

\begin{tabular}{|c|c|c|c|c|}
\hline & $\begin{array}{l}\text { Pooled OLS } \\
\text { Model } 5\end{array}$ & $\begin{array}{l}\text { Pooled OLS } \\
\text { Model } 6\end{array}$ & $\begin{array}{l}\text { Fixed effect } \\
\text { Model } 7\end{array}$ & $\begin{array}{l}\text { Fixed effect } \\
\text { Model } 8\end{array}$ \\
\hline Government management operating grants $(\mathrm{t})$ & $\begin{array}{l}0.406^{* * *} \\
(0.173)\end{array}$ & & $\begin{array}{l}0.126 \\
(0.227)\end{array}$ & \\
\hline Government research grants and contracts $(\mathrm{t})$ & $\begin{array}{l}0.471 * * * \\
(0.118)\end{array}$ & & $\begin{array}{l}0.150 \\
(0.160)\end{array}$ & \\
\hline Government management operating grants (t-1) & & $\begin{array}{l}0.436^{* * * *} \\
(0.132)\end{array}$ & & $\begin{array}{l}0.199 \\
(0.278)\end{array}$ \\
\hline Government research grants and contracts $(\mathrm{t}-1)$ & & $\begin{array}{l}0.463 * * * \\
(0.0966)\end{array}$ & & $\begin{array}{l}0.0918^{*} \\
(0.0470)\end{array}$ \\
\hline Stock & $\begin{array}{c}-0.147 \\
(0.103)\end{array}$ & $\begin{array}{c}-0.162 \\
(0.101)\end{array}$ & $\begin{array}{l}-0.202 * * \\
(0.0853)\end{array}$ & $\begin{array}{c}-0.180 \\
(0.104)\end{array}$ \\
\hline Income & $\begin{array}{l}0.105 \\
(0.115)\end{array}$ & $\begin{array}{l}0.0687 \\
(0.110)\end{array}$ & $\begin{array}{l}0.821 \\
(0.505)\end{array}$ & $\begin{array}{l}0.678 \\
(0.549)\end{array}$ \\
\hline Constant & $\begin{array}{l}1.125 \\
(2.187)\end{array}$ & $\begin{array}{l}1.187 \\
(1.891)\end{array}$ & $\begin{array}{l}5.691 \\
(4.101)\end{array}$ & $\begin{array}{l}6.347 \\
(5.186)\end{array}$ \\
\hline University-fixed & No & No & Yes & Yes \\
\hline Observations & 153 & 153 & 153 & 153 \\
\hline R-squared & 0.857 & 0.865 & 0.079 & 0.089 \\
\hline Number of universities & & & 17 & 17 \\
\hline
\end{tabular}

Robust standard errors in parentheses

$* * * p<0.01, * * p<0.05, * p<0.1$

The within R-squared is reported for the fixed-effects models

increase (Model 6). However, when university-fixed effects were controlled, management operating grants did not have a statistically significant effect on Japanese donations (Models 7 and 8). Therefore, the size of government operating grants' effect on donations disappears when we control for observed or unobserved institutional traits. These traits may include the characteristics of universities - such as institutional type, history, and culture - and the results imply that the change in government operating grants have no additional effect on each university's donation trend. Conversely, the effect of the previous year's research grants had a statistically positive effect on Japanese donations, implying that research grants at $\mathrm{t}-1$ determine donations at $t$. One reason may be that Japanese national universities consider those property gifts contributed by faculty members and obtained using faculty research grants to be donations.

\section{Discussion}

The most important finding of this study was that higher stock prices induce American public research universities' donations, but not those to Japanese universities. This finding suggests that rising stock prices do not always induce donations; this is contrary to previous findings, where stock prices have been considered one of the most influential variables positively correlated with higher education donations (e.g., Clotfelter 2003; Drezner 2007; Smith and Ehrenberg 2003). The difference between the structures of American and Japanese charitable deductions for appreciated property gifts may explain this. Additionally, since the Japanese government has not incentivized donations of appreciated property to universities, national 
universities have only been able to operate financial instruments with risk-free assets and have rarely received stock donations. In contrast, American universities have historically viewed stock donations as essential resources. When the Tax Reform Act of 1986 was enacted, wealthy donors could no longer deduct the fair market value of appreciated property gifts from their taxable incomes. ${ }^{18}$ Many university administrators and researchers stated before the Congress that appreciated property gifts were essential sources for American higher education (Fukui 2018). Subsequently, the Omnibus Budget Reconciliation Act of 1993 revised tax structures to give tax benefits for appreciated property gifts. ${ }^{19}$ These historical differences in stock donations and charitable deductions for appreciated property seem to partially explain why Japanese higher education has not succeeded in increasing donations, and why American higher education has received such large donations. Thus, it is important to consider each country's tax structure when seeking possible links between stock prices and donations to universities.

Second, this paper further suggests that government operational appropriations' effect is not associated with Japanese or American public research universities' donations. This finding is contrary to previous studies that suggested the crowding-in effect (Cheslock and Gianneschi 2008; Marudas and Jacobs 2004; Payne 2001) and crowding-out effect between government funding and universities' donations (Leslie and Ramey 1988; Liu 2006). This inconsistency might be due to the difference in data periods used in this (mid-2000s to late 2010s) and previous studies (before early 2000s). While past studies argued that government appropriations might serve as an endorsement of the quality and reliability of donors (e.g., Cheslock and Gianneschi 2008; Payne 2001), since the 2000s, universities have actively provided information about their activities online and through social media (Peruta and Shields 2017). Donors can now more easily obtain information about university activities. Thus, the level of government funding may no longer be the primary method for donors to gauge the quality of university activities. Second, given that university activities and aims are diverse, government funds might not cover areas that donors wish to support (Cheslock and Gianneschi 2008). Although further research should be undertaken to investigate the reasons, this finding is in line with $\mathrm{Lu}$ (2016), who conducted a meta-analysis of government funding and donations to nonprofit organizations and found that "government grants have almost no correlation with private donation" (p. 381).

Third, this paper found a positive relationship between the previous year's government research grants and donations in the case of Japanese national universities. However, a note of caution is due here, as this result may be explained by the rules governing Japanese research grant use. The funding agency - the Japan Society for the Promotion of Science - stipulates the following spending rule for Grants-in-Aid for Scientific Research: "Upon the purchase of equipment with direct expense, the Principal Investigator is to immediately donate the items to his/her research institution" (2019, p. 7). This means that "donations" listed in Japanese universities' financial statements include property gifts contributed by the faculty and obtained with research grants. Due to this rule, the previous year's research grants could have a positive effect on donations even if Japanese donors may not regard research grants as an endorsement of institutional quality.

These findings have important implications for higher education policymakers who encourage donations to universities. First, these policymakers should realize that decreasing

\footnotetext{
${ }^{18}$ Staff of the Joint Committee on Taxation (May 4, 1987). General Explanation of the Tax Reform Act of 1986.

${ }^{19}$ Staff of the Joint Committee on Taxation. (August 23, 1993). Summary of the Revenue Provisions of The Omnibus Budget Reconciliation Act of 1993 (H.R. 2264).
} 
trends of government appropriations to universities does not induce donors. The Japanese government tends to explain a need for donations to compensate for decreasing trends of government appropriations, but this kind of message may not be enough to attract donors. Second, one of the policy options for increasing donations to higher education is to create or maintain tax policies allowing donors to deduct the fair market value of property gifts from their taxable income and providing an exemption from capital gains taxes. These tax policies, in particular, reduce the net cost of donors when the capital markets rise and induce donations of stocks to higher education.

\section{Conclusion}

The goal of this article was twofold: to examine whether the capital market trends affect the donation revenue of public research universities operating under the different tax systems of Japan and the USA, and to investigate how the level of government support for higher education affects American and Japanese public research universities' donations in the era of government budget constraints. The panel data analysis found that trends in capital markets only positively affect donations to public research universities under the US, but not Japanese, tax structure. This finding suggests that increasing trends in public research universities' donations can be achieved, not solely through strong capital markets as mentioned by previous studies but through a combination of strong capital markets and tax policies that reduce the actual price of giving when stock prices increase. The second major finding was that decreasing trends in government appropriations to public research universities did not affect donations to either American or Japanese public research universities. This new understanding should be helpful to policymakers and university administrators who intend to encourage donations for higher education. First, it is essential that policymakers design tax structures and environments that are not a disincentive for donors when capital markets expand. Second, higher education policymakers and university administrators who organize fundraisers should remember that decreasing trends in government funding does not necessarily attract donors.

Although these study's findings advance understanding of the relationship between public policies, capital markets, and donative behavior at public research universities from an international comparative viewpoint, future research should emphasize the conceptual model's comprehensive testing. Future studies should include fundraising costs to examine each university's level of fundraising activity, which may elucidate why government appropriations did not correlate with donations to public research universities - was it because universities could not invest in fundraising activities due to budget constraints or because donors did not care about government funding levels when they donated to public research universities? Future studies must also demonstrate recent tax reforms' effects in both countries. Since 2018, the Japanese government has encouraged appreciated property gifts to national universities and reformed the system to allow universities to easily retain stocks (Fiscal Year 2018 Japan Tax Reform). Conversely, US tax policies have recently moved in the opposite direction, as the Tax Cuts and Jobs Act of 2017 (P.L. 115-97) reduced donor incentives. ${ }^{20}$ More information on

\footnotetext{
${ }^{20}$ The Tax Cuts and Job Act of 2017 doubled standard deductions for some taxpayers and reduced the number of taxpayers who used itemized deductions. Since charitable deductions can only be claimed by taxpayers who used itemized deductions, it might determine disincentives for giving.
} 
the effects of these changes would help policymakers more accurately establish the role of tax policies in higher education.

Acknowledgments I am grateful to Prof. Drezner, Noah (Associate Professor at Teachers College Columbia University) and Prof. Yamamoto, Kiyoshi (Emeritus Professor at The University of Tokyo) for helpful comments and discussions. I would also like to thank Prof. Campbell, Corbin, Prof. O’Connell, Patrick, and Prof. Shields, James for the hospitality during my visit at the Teachers College Columbia University as a Fulbright visiting scholar, where the main results of this paper were obtained.

Conflict of interest The author declares that he has no conflict of interest.

Funding information This study was funded by MEXT/JSPS KAKENHI (grant number 17K14015), and the Fulbright Scholar Program supported my research activities in the USA.

Open Access This article is licensed under a Creative Commons Attribution 4.0 International License, which permits use, sharing, adaptation, distribution and reproduction in any medium or format, as long as you give appropriate credit to the original author(s) and the source, provide a link to the Creative Commons licence, and indicate if changes were made. The images or other third party material in this article are included in the article's Creative Commons licence, unless indicated otherwise in a credit line to the material. If material is not included in the article's Creative Commons licence and your intended use is not permitted by statutory regulation or exceeds the permitted use, you will need to obtain permission directly from the copyright holder. To view a copy of this licence, visit http://creativecommons.org/licenses/by/4.0/.

\section{References}

Andreoni, J. (1989). Giving with impure altruism: applications to charity and Ricardian equivalence. Journal of Political Economy. https://doi.org/10.1086/261662.

Andreoni, J. (2006). Philanthropy. In S. C. Kolm, \& J. M. Ythier (Eds.), Handbook of the economics of giving, altruism and reciprocity, Vol. 2, (pp. 1201-1269). Amsterdam: North Holland. https://doi.org/10.1016 /S1574-0714(06)02018-5.

Andreoni, J., \& Payne, A. A. (2003). Do government grants to private charities crowd out giving or fund-raising? The American Economic Review, 93(3), 792-812.

Bekkers, R., \& Wiepking, P. (2011). A literature review of empirical studies of philanthropy: eight mechanisms that drive charitable giving. Nonprofit and Voluntary Sector Quarterly. https://doi.org/10.1177 /0899764010380927.

Bristol Jr., R. (1992). How much will alumni give in the future? Planning for Higher Education, 20(2), 1-12.

Cheslock, J. J., \& Gianneschi, M. (2008). Replacing state appropriations with alternative revenue sources: the case of voluntary support. The Journal of Higher Education. https://doi.org/10.1353/jhe.2008.0012.

Clotfelter, C. T. (2003). Alumni giving to elite private colleges and universities. Economics of Education Review. https://doi.org/10.1016/S0272-7757(02)00028-6.

Cook, W. B. (1997). Fund raising and the college presidency in an era of uncertainty: from 1975 to the present. The Journal of Higher Education. https://doi.org/10.1080/00221546.1997.11778977.

Coughlin, C. C., \& Erekson, O. H. (1986). Determinants of state aid and voluntary support of higher education. Economics of Education Review. https://doi.org/10.1016/0272-7757(86)90010-5.

Drezner, N. D. (2007). Recessions and tax-cuts: Economic cycles' impact on individual giving, philanthropy, and higher education. International Journal of Educational Advancement. https://oi.org/10.1057/palgrave. ijea.2150036.

Drezner, N. D. (2011). Philanthropy and fundraising in American higher education. San Francisco: Jossey-Bass.

Drezner, N. D. (2019). The global growth of higher education philanthropy and fundraising. In Y. R. Natasha \& T. Arushi (Eds.), Philanthropy in education (pp. 90-104). Cheltenham: Edward Elgar Publishing.

Duquette, N. J. (2016). Do tax incentives affect charitable contributions? Evidence from public charities' reported revenues. Journal of Public Economics. https://doi.org/10.1016/j.jpubeco.2016.02.002.

Fukui, F. (2012). Time series analysis of individual donations to U.S. higher education institutions: focusing on the role of capital markets and federal tax policy. Japanese Journal of Higher Education Research, 15, 201220 . 
Fukui, F. (2018). Amerikakoutoukyouiku no kakudaisuru kojinkihu [growth of personal donations in U.S. higher education]. Tokyo: Toshindo.

Gaudiani, C. (2004). The greater good: How philanthropy drives the American economy and can save capitalism. New York: Henry Hold and Company.

Gerring, J., \& Cojocaru, L. (2016). Selecting cases for intensive analysis: a diversity of goals and methods. Sociological Methods \& Research. https://doi.org/10.1177/0049124116631692.

Hashimoto, K. (2017). Japan's "super global universities" scheme: Why does the number of "foreign" students matter? In A. W. Ata, L. T. Tran, \& I. Liyanage (Eds.), Educational reciprocity and adaptivity: International students and stakeholders (pp. 25-44). London: Routledge.

Havens, J. J., O’Herlihy, M. A., \& Schervish, P. G. (2006). Charitable giving: How much, by whom, to what, and how. In W. W. Powell \& R. Steinberg (Eds.), The nonprofit sector: a research handbook (2nd ed., pp. 542567). New Haven: Yale University Press.

Holmes, J. (2009). Prestige, charitable deductions and other determinants of alumni giving: Evidence from a highly selective liberal arts college. Economics of Education Review. https://doi.org/10.1016/j. econedurev.2007.10.008.

Jackson, R. L. (2013). The prioritization of and time spent on fundraising duties by public comprehensive university presidents. International Journal of Leadership and Change, 1(1), 9.

Japan Society for the Promotion of Science. (2019). Grants-in-Aid for Scientific Research (KAKENHI Multi-year Fund)_ "Fund for the Promotion of Joint International Research (Fostering Joint International Research A)" Spending Rules: Funding Conditions, Japan Society for the Promotion of Science. https://www.jsps.go. jp/j-grantsinaid/16_rule/data/rule/01_d1/2019_kyoka_fundingconditions.pdf. Accessed 17 Dec 2019.

Japanese Central Council for Education. (2018). 2040 nen ni muketa koutoukyouiku no grandodezain [grand design of higher education in Japan towards 2040], Ministry of Education, Culture, Sports, Science and Technology. http://www.mext.go.jp/component/b_menu/shingi/toushin/_icsFiles/afieldfile/2018/12/20 /1411360_1_1_1.pdf. Accessed 25 May 2019.

Johnstone, D. B., Arora, A., \& Experton, W. (1998). The financing and management of higher education: A status report on worldwide reforms. Washington, DC: World Bank.

Kaneko, M. (2009). Incorporation of national universities in Japan: design, implementation and consequences. Asia Pacific Education Review, 10(1), 59-67.

Kaplan, A. E. (2018). 2017 voluntary support of education. New York: Council for Aid to Education.

Leslie, L. L., \& Ramey, G. W. (1988). Donor behavior and voluntary support for higher education institutions. The Journal of Higher Education. https://doi.org/10.1080/00221546.1988.11778318.

Leslie, L., Drachman, S. S., Conrad, C. F., \& Ramey, G. W. (1983). Factors accounting for variations over time in voluntary support for colleges and universities. Journal of Education Finance, 9(2), 213-225.

Lister, D. (2013). The appearance of impropriety. In J. G. Pettey (Ed.), Nonprofit fundraising strategy: a guide to ethical decision making and regulation for nonprofit organizations (pp. 17-34). Hoboken: John Wiley \& Sons.

Liu, Y. (2006). Determinants of private giving to public colleges and universities. International Journal of Educational Advancement. https://doi.org/10.1057/palgrave.ijea.2150014.

$\mathrm{Lu}, \mathrm{J}$. (2016). The philanthropic consequence of government grants to nonprofit organizations: a meta-analysis. Nonprofit Management \& Leadership. https://doi.org/10.1002/nml.21203.

Marudas, N. P., \& Jacobs, F. A. (2004). Determinants of charitable donations to large U.S. higher education, hospital, and scientific research NPOs: new evidence from panel data. Voluntas: International Journal of Voluntary and Nonprofit Organizations, 15(2), 157-179 https://ink.springer.com/content/pdf/10.1023 \%2FB\%3AVOLU.0000033179.47685.1c.pdf. Accessed 25 May 2019.

McClure, K. R. (2015). Exploring curricular transformation to promote innovation and entrepreneurship: an institutional case study. Innovative Higher Education. https://doi.org/10.1007/s10755-015-9325-8.

Mill, J. S. (1843). A system of logic. London: Longmans, Green, and Co..

Mitsuda, Y. (2004). Carnegie type classification of Japanese universities and colleges. The Journal of Finance and Management in Colleges and Universities, 1, 71-82.

Monks, J. (2003). Patterns of giving to one's alma mater among young graduates from selective institutions. Economics of Education Review. https://doi.org/10.1016/S0272-7757(02)00036-5.

Morphew, C. C., \& Baker, B. D. (2004). The cost of prestige: Do new research I universities incur higher administrative costs? The Review of Higher Education, 27(3), 365-384.

National Association of State Universities and Land Grant Colleges. (1966). Margin for excellence: the role of voluntary support in public higher education. Washington, DC: National Association of State Universities and Land Grant Colleges, Office of Institutional Research.

OECD. (2007). On the edge: Securing a sustainable future for higher education. OECD Education Working Papers. https://doi.org/10.1787/220180871707. 
Ohman, E. M., Douglas, P. S., Dean, L. B., \& Ginsburg, G. S. (2016). Philanthropy for science: Is it a viable option? Circulation Research. https://doi.org/10.1161/CIRCRESAHA.116.309657.

Okunade, A. A., Wunnava, P. V., \& Walsh Jr., R. (1994). Charitable giving of Alumni: Micro-Data Evidence from a Large Public University. American Journal of Economics and Sociology. https://doi.org/10.1111 /j.1536-7150.1994.tb02674.x.

Okuyama, N., \& Yamauchi, N. (2015). Giving in Japan: The role of philanthropy in strengthening civil society. In P. Wiepking \& F. Handy (Eds.), The Palgrave handbook of global philanthropy (pp. 404 425). London: Palgrave Macmillan. https://doi.org/10.1057/9781137341532_24.

Onishi, T. (2007). Japanese fundraising: a comparative study of the United States and Japan. International Journal of Educational Advancement. https://doi.org/10.1057/palgrave.ijea.2150062.

Payne, A. A. (2001). Measuring the effect of federal research funding on private donations at research universities: is federal research funding more than a substitute for private donations? International Tax and Public Finance. https://doi.org/10.1023/A:10128432.

Peruta, A., \& Shields, A. B. (2017). Social media in higher education: understanding how colleges and universities use Facebook. Journal of Marketing for Higher Education. https://doi.org/10.1080 /08841241.2016.1212451.

Przeworski, A., \& Teune, H. (1970). The logic of comparative social inquiry. New York: Wiley.

Reynolds, N. L., Simintiras, A. C., \& Diamantopoulos, A. (2003). Theoretical justification of sampling choices in international marketing research: key issues and guidelines for researchers. Journal of International Business Studies, 34(1), 80-89.

Roberts, R. D. (1984). A positive model of private charity and public transfers. Journal of Political Economy, 92(1), 136-148.

Rohayati, M. I., Najdi, Y., \& Williamson, J. C. (2016). Philanthropic fundraising of higher education institutions: A review of the Malaysian and Australian perspectives. Sustainability. https://doi.org/10.3390/su8060541.

Rose-Ackerman, S. (1986). Do government grants to charity reduce private donations? In S. Rose-Ackerman (Ed.), The economics of nonprofit institutions: studies in structure and policy (pp. 313-329). New York: Oxford University Press.

Salmi, J. (2009). The challenge of establishing world class universities. Geneva: The World Bank.

Skari, L. A. (2014). Community college alumni: predicting who gives. Community College Review. https://doi. org/10.1177/0091552113510172.

Slaughter, S., \& Leslie, L. L. (1997). Academic capitalism: Politics, policies, and the entrepreneurial university. Baltimore: JHU Press.

Smith, C. L., \& Ehrenberg, R. G. (2003). Sources and uses of annual giving at private research universities. New Directions for Institutional Research. https://doi.org/10.1002/ir.85.

Stephenson, A. L., \& Bell, N. (2014). Motivation for alumni donations: a social identity perspective on the role of branding in higher education. International Journal of Nonprofit and Voluntary Sector Marketing, 19(3), $176-186$

Sunami, A. (2017). Japan university reform "unrealistic" without proper funding. Nature Index. https://www. natureindex.com/news-blog/japan-university-reform-unrealistic-without-proper-funding. Accessed 1 Dec 2019.

Sung, C. I. (2016). Investigating philanthropy initiatives in Chinese higher education. Voluntas: International Journal of Voluntary and Nonprofit Organizations. https://doi.org/10.1007/s11266-014-9509-3.

The University of Tokyo. (2004). Tokyo-Daigaku-Kihu-Toriatukai-Kisoku [The University of Tokyo Donation Handling Rules]. https://www.u-tokyo.ac.jp/gen01/reiki_int/reiki_honbun/au07408511.html. Accessed 1 Dec 2019.

van de Vijver, F. J., \& Leung, K. (1997). Methods and data analysis for cross-cultural research. London: Sage Publication.

Walker, A. G. (2015). Division I intercollegiate athletics success and the financial impact on universities. $S A G E$ Open. https://doi.org/10.1177/2158244015611186.

Warr, P. G. (1982). Pareto optimal redistribution and private charity. Journal of Public Economics, 19, 131-138.

Wiepking, P., \& Bekkers, R. (2012). Who gives? A literature review of predictors of charitable giving part two: Gender, family composition and income. Voluntary Sector Review. https://doi.org/10.1332/204080512 X649379.

Zhang, Y. (2018). China, Japan and the US stock markets and the global financial crisis. Asia-Pacific Financial Markets, 25(1), 23-45.

Publisher's note Springer Nature remains neutral with regard to jurisdictional claims in published maps and institutional affiliations. 